\title{
IPTEKS BAGI KEWIRAUSAHAAN (IbK) DI UNIVERSITAS MUHAMMADIYAH MAKASSAR (Peningkatan Kualitas Produk Tenan Melalui Pelatihan Ibk)
}

\author{
Abubakar Idhan 1), Ratnawati Tahir ${ }^{2}$ ), Syamsia ${ }^{3}$ ), Tahnur ${ }^{4}$ ) \\ Fakultas Pertanian, Universitas Muhammadiyah Makassar 1), 2), 3),4)
}

\begin{abstract}
Science and Technology for Entrepreneurship (IbK) at the University of Muhammadiyah Makassar aims to improve the knowledge and skills of students who have started pioneering a product as a forerunner of independent business through the Student Creativity Program (PKM), and alumni are starting a new business (entrepreneurship), creating new entrepreneursindependentlybased science and technology and creating an entrepreneurial training methods suitable for the tenant. IbK activities take place during the first three years to build as many as 20 tenants consisting of the students who have EnterpreneurshipStudent Creativity Program (PKM-K) active students and alumni PKM-K, and, of the 20 tenants that have generated new independent entrepreneurs as many as five (5); among others: (1) The business of Fermented Milk (for health and cosmetics), (2) Shoes Sabbe /Silk Bugis, (3) Crackers Cassava and Banana, (4) Shredded Chilli, (5) Pin and Keychain. Specific targets to be achieved throughIBK activities are spawned at least 5 participants IBK become new entrepreneurs based independent science and technology, at least $80 \%$ of participants prospective entrepreneurs first year to new entrepreneurs. Training Methods entrepreneurial knowledge in the form of lectures, training to improve product quality and improved packaging tenant.

The Results of IbK in the first year of activities, namely; Enterprises of fruit and vegetable fermentation, Souvenir glass bamboo, Flowers Products Terrarium, fish fry and Miniature Boat Pinisi. Increasing the quantity and quality of production of the tenants have pushed their motivation to be more diligent in terms of marketing their products. There are two ways that do marketing tenanare included in the category of an Independent ie depending on the type of production the tenants, such as for the production of fermented milk and pin / key holder by way of order. As for the tenants who produce; Cassava crackers and bananas, chili, as well as silk shoes/sabbe consignment
\end{abstract}

Keywords: Training, self-employment, production, marketing 


\section{PENDAHULUAN}

Kegiatan kewirausahaan mahasiswa di Universitas Muhammadiyah Makassar sejak tahun 2008 mengalami perkembangan yang cukup pesat hal ini dapat dilihat dari peningkatan jumlah proposal Program Kreativitas Mahasiswa Kewirausaan yang diajukan mahasiswa setiap tahunnya mengalami peningkatan. Pada tahun 2010 terdapat 6 proposal yang lolos, tahun 2011 meningkat menjadi 21 proposal dan tahun 2012 meningkat menjadi 29 proposal kewirausahaan, tahun 2013 sebanyak 62 judul dan pada tahun 201479 judul. Jadi dalam empat tahun terakhir yaitu tahun 2010 sampai dengan 2014 terdapat 197 judul kegiatan/proposal kewirausahaan yang didanai oleh Dikti melalui kegiatan Program Kreativitas Mahasiswa Kewirausahaan (PKMK). Sedangkan kegiatan Program kegiatan kewirausahaan lain terdapat 10 judul berhasil mendapatkan dana kewirausahaan Bank Mandiri pada tahun 2011. Terdapat pula kegiatan kewirausahaan yang didanai oleh Kopertis Wilayah IX pada tahun 2010 sebanyak 2 judul.Setiap judul proposal yang diajukan minimal beranggotakan 3 orang dan maksimal 5 orang.

Jumlah mahasiswa yang merintis usaha baru 11 orang adalah Produk atau komoditas yang telah dijual adalah sayuran dalam pot, abon ikan, aneka kreasi bros, kap lampu dari limbah soft drink, pupuk organik dari limbah enceng gondok, telur asin aneka rasa, teh rosella, agaragar kering, media tanam (arang sekam), POC (pupuk organik cair), terrarium, tanaman hias dan ipik makanan penambah stamina.

Produk yang dihasilkan oleh mahasiswa dalam kegiatan usahanya memiliki potensi nilai jual dan unik serta memiliki potensi yang cukup besar untuk dikembangkan khususnya sebagai oleh-oleh khas dari Sulawesi Selatan. Pemilihan produk didasarkan pada ciri khas daerah Sulawesi Selatan sebagai salah satu upaya pelestarian nilai-nilai budaya baik untuk produk kuliner maupun hiasan. Produk kuliner khas hasil kewirausahaan mahasiswa melalui PKMK yang didanai oleh Dikti diantaranya adalah abon ikan gabus aneka rasa, ipik makan penambah stamina, pizza khas Palopo, Tango Bugis, Sarabba instan. Budidaya jamur dengan memanfaatkan limbah kayu untuk produk kuliner. Terdapat pula produk hiasan bernuansa sutra (lipa sabbe khas bugis), diner set batik, replika kupu-kupu, diner set ala tempurung kelapa,aneka kap lampu dari limbah soft drink, terrarium, mug lontara, kaos motif karikatur rumus fisika, komik lontara bugis, lampu hias dari cangkang telur, payung motif batik. Selain pengembangan produk, kewirausahaan mahasiswa juga mengelola jasa klinik agribisnis. Produk mahasiswa yang lain yang mempunyai nilai ekonomi dan potensi yang cukup baik adalah telur asin aneka rasa. Produk telur asin yang dijual berbeda dengan telur asin yang dijual selama ini, produk asin yang dihasilkan memiliki aroma yang khas seperti aroma bawang putih dan jahe. Sayuran dalam pot juga mempunyai peluang dan nilai ekonomi yang cukup tinggi, karena selain bermanfaat sebagai bahan sayur segar (petik sendiri) juga berfungsi sebagai tanaman hias dan memperindah halaman rumah, pupuk organik dari enceng gondok, bibit mangga okulasi merupakan kegiatan kewirausahan mahasiswa secara mandiri yang awalnya dari kegiatan praktikum mata kuliah di program studi agribisnis.

Kendala yang yang dihadapi di dalam membentuk wirausaha yang mandiri yaitu karena mahasiswa belum memiliki pengalaman berinteraksi dengan dunia usaha sehingga hal ini salah satu masalah yang ada, serta belum mampunya mahasiswa dalam mengatur waktu antara kegiatan akademik dengan kegiatan usaha yang dijalankan dan masih adanya perasaan malu di dalam melakukan kegiatan pemasaran hasil produksi yang mereka hasilkan.

Melihat kegiatan-kegiatan usaha yang telah dilakukan oleh mahasiswa, maka perlu dilakukan kegiatan-kegiatan pelatihan untuk menambah pengetahuan pembuatan produk dan manajemen bisnis, begitu juga kegiatan pemagangan untuk menambah keterampilan wirausaha bagi tenant. Kegiatan pendampingan, pembimbingan dan konsultasi juga perlu dilakukan untuk memberikan bimbingan bagi tenant dalam melakukan kegiatan usaha serta perlu dilakukan kegiatan sarasehan dunia usana dengan mendatangkan pembicara tamu dari pengusaha sukses untuk memberikan motivasi kepada tenant serta temu bisnis, diperlukan agar mahasiswa di dalam menjalankan usahanya dapat berjalan dengan baik dan memiliki jaringan kerja yang luas, sehingga mahasiswa 
tersebut dapat menjadi wirausaha baru yang mandiri.

Program IbK ini melibatkan semua program studi yang ada di Universitas Muhammadiyah Makassar yang terdiri atas prodi agribisnis, kehutanan, budidaya perairan, teknik elektro, teknik irigasi, teknik arsitek, administrasi dan pemerintahan, prodi akuntansi, prodi manajemen, prodi kedokteran, prodi bahasa indonesia, prodi bahasa inggris, prodi matematika, prodi seni, prodi bahasa arab. sehingga keberadaan IbK ini betul-betul dirasakan manfaatnya oleh seluruh mahasiswa dan alumni yang terlibat dalam wirausaha.

\section{KAJIAN LITERATUR}

Bank Indonesia (BI) menilai bahwa perkembangan wirausaha di Indonesia masih terbilang minim. Hal ini tercermin dari populasi wirausaha baru mencapai angka 1,65 persen dari jumlah penduduk Indonesia.

"Perkembangan wirausaha Indonesia masih terbatas. Hal ini tercermin dari tiga hal. Pertama, Populasi wirausaha baru mencapai angka 1,65 persen dari jumlah penduduk, jauh tertinggal dibandingkan dengan negara tetangga seperti Malaysia, Thailand, dan Singapura yang sudah mencapai di atas 4 persen," ungkap Deputi Gubernur Bank Indonesia, Halim Alamsyah saat membuka acara Entrepreneurship Strategic Policy Forum dengan tema "Policy Recommendation on Entrepreneurship Ecosystem Development in Indonesia", Jumat (21/11/2014).

Kewirausahaan memiliki peranan penting untuk menjadikan masyarakat lebih kreatif dan mandiri. Di Indonesia sendiri jumlah wirausahawan adalah sebesar $19,3 \%$ dari jumlah total penduduk dewasa. Dengan adanya kewirausahaan masyarakat dapat mempunyai kemampuan untuk menciptakan dan menyediakan produk yang bernilai tambah atau inovasi-inovasi yang baru sehingga dapat menjadikan masyarakat lebih kreatif dalam menyampaikan ide-ide dan kreasinya, mereka bisa menciptakan barang yang dirasa perlu dan penting untuk kesejahteraan masyarakat itu sendiri sehingga tidak perlu mengimpor dari luar negeri. Selain itu masyarakat tidak tergantung dengan pemerintah seperti tenaga kerja negri (PNS) yang masih di gaji oleh pemerintah, bahkan seorang wirausaha akan mendatangkan omset yang akan di berikan ke negara melalui pajak. Secara tidak langsung kesejahteraan ekonomi masyarakat bisa stabil.

Hal kesehatan ekosistem kewirausahaan, Indonesia menempati peringkat ke-68 dari 121 negara di dunia menurut The Global Entrepreneurship \& Development Index 20145. Sementara yang ketiga, berdasarkan The EY G20 Entrepreneurship Barometer 2013, Indonesia di antara negara-negara G20 termasuk dalam kuartil keempat yaitu kelompok negara yang memiliki ranking terendah dalam ekosistem kewirausahaan.

Bank Indonesia telah menyelenggarakan Entrepreneurship Strategic Policy Forum dengan tema "Policy Recommendation on Entrepreneurship Ecosystem Development in Indonesia yang diharapkan dapat merumuskan rekomendasi mengenai kebijakan di tingkat nasional dalam rangka membangun ekosistem kewirausahaan di Indonesia. Target kegiatannya adalah menumbuhkan wirausaha baru dari kalangan mahasiswa, eks TKI dan masyarakat umum dari berbagai sektor usaha seperti industri pengolahan, pertanian, perdagangan dan sebagainya.

Kemudian pada tahun 2014 Bank Indonesia melaksanakan program pengembangan wirausaha yang bertujuan untuk meningkatkan jumlah wirausaha di sektor agribisnis dan berorientasi ekspor dalam rangka mendukung ketahanan pangan dan struktur neraca perdagangan. Langkah-langkah yang ditempuh Bank Indonesia tersebut sejalan dengan tujuan dari kegiatan IbK di Universitas Muhammadiyah Makassar.

\section{METODE}

Dalam kegiatan kewirausahaan tenant diambil dari mahasiswa yang melakukan kegiatan PKMK dan kegiatan kewirausahaan lainnya, serta alumni Universitas Muhammadiyah Makassar yang melakukan kegiatan usaha, dengan pola rekruitmen tenant dilakukan sebagai berikut:

\section{a. Membuka pendaftaran peserta untuk dibina sebagai te nant}

Syarat Peserta:

1. Mahasiswa peserta PKMK/Mahasiswa wirausaha baru dan alumni

2. Memiliki motivasi yang kuat untuk menjadi wirausahaan

3. Bersedia mengikuti program IbK 
Prosedur Pendaftaran

1. Mengambil formulir pendaftaran di sekretariat IbK

2. Calon peserta binaan IbK mengisi semua isian formulir

3. Mengirim CV terbaru, ringkasan usaha dan riwayat akademis

4. Formulir dikembalikan ke sekretariat IbK

\section{b. Seleksi peserta IbK}

Dilakukan oleh pengelola IbK dengan mengacu kepada syarat-syarat peserta, selain peserta tenaga konsultan atau nara sumber juga dilakukan seleksi berdasarkan dengan kepakaran dan kebutuhan dari tenant.

\section{c. Pola Pemberian Teknologi}

Pemberian teknologi dilakukan melalui pelatihan dan praktik produk yang dilaksanakan oleh pengelola IbK.

\section{d. Teknik Pembiayaan Tenant}

Untuk mendukung kelancaran usaha tenant, maka perlu adanya teknik pembiayaan tenant secara profesional. Adapun sumber pembiayaan pada tahap pelatihan dibiayai melalui IbK Perguruan Tinggi, bentuk pinjaman yang harus dikembalikan oleh tenant. Adapun tekniknya yaitu dengan cara mengangsur kepada IbK Universitas, dari hasil produksi tenant dijual kepada mitra yang sudah disepakati harganya dan bantuan pembiayaan yang diperoleh dipotong dari hasil penjualan, atau berdasarkan kesepakatan antara tenant IbK Universitas.

\section{HASIL DAN PEMBAHASAN}

Pelaksanaan IbK tahun pertama ini telah dilakukan diawali dengan perekrutan tenan yang akan diseleksi menjadi peserta. Pada tahap pertama dinyatakan memenuhi syarat sebagai peserta sebanyak 20 tenan dari 30 peminat. Pada bulan pertama sampai kedua pelaksanaan kegiatan tetap dikutkan sebanyak 30 tenan dengan tujuan untuk mendapatkan materi tentang motivasi berwirausaha dan manajemen pengelolaan usaha dan keuangan. Pada bulan ketiga sampai keempat mengerucut sampai 20 tenan yang diikutkan dalam pelatihan produksi, selama dua bulan tersebut para tenan dilatih dan dievaluasi hasil kegiatan dan produksi yang dihasilkan, yang dikhususkan pada penilaian kualitas produksinya. Memasuki bulan kelima sampai keenam kegiatan diikutkan sepuluh tenan sebagai cikal bakal untuk menjadi tenan yang mandiri berbasis iptek.

Rangkaian kegiatan sampai pada bulan keenam oleh tim IbK menetapkan lima tenan yang dianggap memenuhi syarat masuk dalam kelompok mandiri sebagai berikut :

1. Tenan usaha buah dan sayur fermentasi, tenan ini dikelola oleh alumni yang telah berusaha selama satu tahun. Setelah terpilih sebagai peserta IbK pihak tim IbK mendatangkan instruktur dari Komunitas KIEFIR Indonesia yang memberi materi pelatihan perbaikan dan peningkatan kualitan produknya. Pada saat produksinya memenuhi standart maka diadakan persintase pada beberapa perguruan tinggi dan komunitas masyarakat untuk memperkenalkan manfaat buah dan sayur fermentasi tersebut. Saat ini pemasaran dilakukan dengan sistem pesanan dengan harapan kualitas dari produk tersebut tetap terjamin. Contoh produk seperti berikut pada Gambar 1.
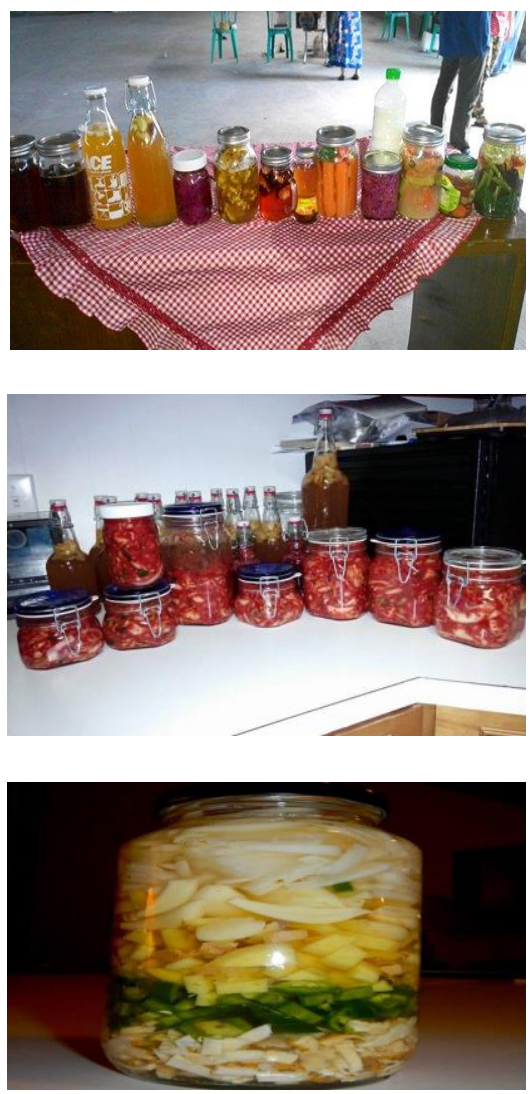


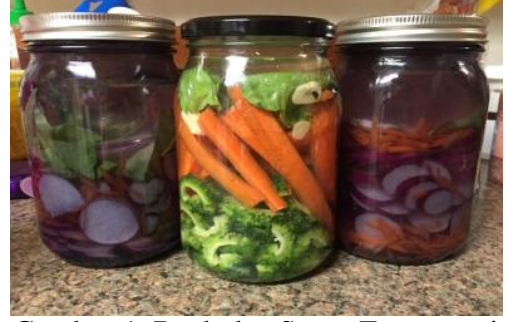

Gambar 1. Buah dan Sayur Fermentasi

2. Tenan Suvenir gelas bambu, tenan ini dikelola oleh alumni PKM-K mahasiswa aktif prodi Bahasa Inggeris FKIP. Aktifitas tenan ini memproduksi suvenir berbahan baku bambu. Mereka dalam aktifitas produknya terlebih dahulu menyiapkan bahan baku bambu yang diawetkan dengan merendam bambu menggunakan air garam selama satu minggu. Sistem pemasaran yang dialkukan dengan cara menitip pada kounter-kounter yang ada di Mall dengan sistem konsinyasi. Pada waktu tertentu bila produknya ada yang tidak laku, maka ditarik kembali untuk direkondisi dengan variasi dan assesoris yang baru yang berbeda sebelumnya. Contoh produk seperti berikut pada gambar 2 .

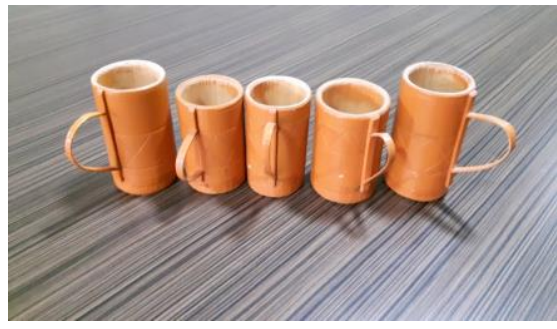

Gambar 2. Suvenir Gelas bambu

3. Produk Bunga Terrarium, tenan ini dikelola oleh alimni PKM-K dari prodi Agribisnis Fakultas Pertanian, produksi bunga terrarium sebagai pembersih udara dalam ruangan menggunakan kembang lida mertua yang mempunyai kemampuan untuk menyerap polutan di udara khususnya dalam ruangan. Sistem pemasaran produk ini dengan menetapkan pelanggang pada perkantoran khususnya dalam kampus, sedang konsumen luar kampus selain perkantoran juga menyasar rumah tangga. Contoh produk seperti berikut pada gambar 3 .

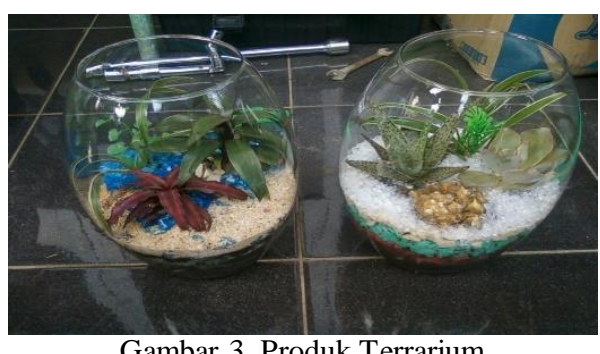

Gambar 3. Produk Terrarium

4. Tenan ikan teri goreng, tenan ini dikelola oleh alumni PKM-K dari prodi Ilmu Kependidikan, prodak ini merupakan hasil lanjutan dari KKN-PPM. Produksi ikan teri goreng dalam kemasang merupakan salah satu antisipasi ketersediaan sepanjang tahun. Bagi penikmat ikan teri goreng menyambut baik hal tersebut karena kebutuhannya akan terpenuhi. Sistem pemasaran secara konsinyasi yang dititip pada toko-toko. Contoh produk seperti berikut pada gambar 4 .

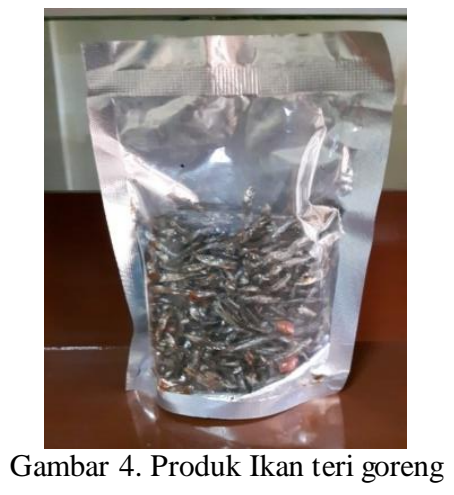

5. Tenan Miniatur Perahu Pinisi, tenan ini dikelola oleh alumni PKM-K mahasiswi FKIP. Sistem pemasaran melalui pesanan dan penitipan pada geray-geray suvenir, dan sering digunakan sebagai suvenir pada acara-acara seminar di kampus. Contoh produk seperti berikut pada gambar 5

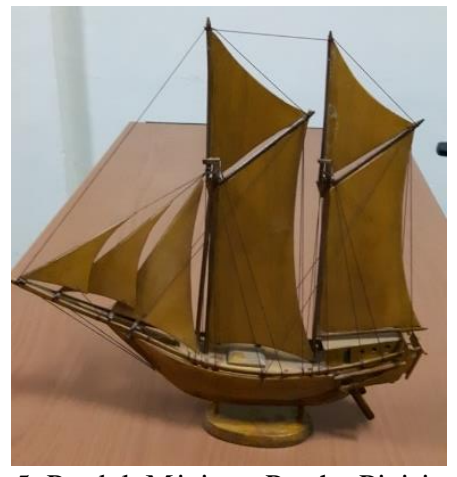

Gambar 5. Produk Miniatur Perahu Pinisi 
Dari target yang direncanakan tersebut, maka dalam pelaksanaan IbK tahun 2015 telah banyak dicapai kemajuan dimana para tenan peserta telah memahami prinsip dasar berwirausaha dalam hal kemampuan mengelola, merencanakan, meningkatkan kualitas produksi, memasarkan dan memahami kehendak pasar. Tenan telah mampu meningkatkan kemampuan dan keterampilan dalam meningkatkan kualitas dan kuantitas produksinya, serta mulai mengembangkan pemasarannya kemasyarakat umum, yang sbelumnya hanya di kalangan kampus. Hal tersebut sejalan dengan pendapat F. Harbison dalam Idhan, A. (2010) bahwa entrepreneurship melaksanakan tiga fungsi pokok yaitu penanggung resiko, inovasi dan manajemen.

\section{KESIMPULAN}

Pelaksanaan IbK dapat meningkatkan kemampuan tenan baik dalam bentuk pemahaman pengelolaan usaha, maupun meningkatan kualitas dan kuantitas produksi melalui pelatihan dan pendampingan oleh tim IbK Unismuh Makassar.

Tenan yang produknya didasari Ipteks dapat memberikan manfaat yang besar utamanya dalam hal efisiensi dan peningkatan produksi.

\section{REFERENSI}

Anonim, 20013. Panduan Pelaksanaan Penelitian dan Pengabdian Kepada Masyarakat di Perguruan Tinggi Edisi IX. direktorat penelitian dan pengabdian kepada masyarakat direktorat jenderal pendidikan tinggi kementerian pendidikan dan kebudayaan

Idhan, A. 2010. Berani Menjadi Entrepreneur (Gagasan, Ide dan Nilai-nilai). Tanda Pustaka, Jl. Jipang No. 3 Makassar. Email ; tanda pustaka@yahoo.com 